\title{
THE AMBIVALENT COMPOSER AND THE CARNEGIE COMPETITION: FROM MUSIC TO LITERATURE
}

\author{
Lynn Mutti
}

Sylvia Townsend Warner's childhood gave her the opportunity to experience both good writing and good music, as shown in the work of her father, George Townsend Warner, a Housemaster at Harrow School, and Dr Percy Buck, Head of Music there. George Townsend Warner was an author of textbooks on history and grammar, and editor of The Harrovian, the school's journal, for many years. Sylvia Townsend Warner may have had her first prose published as early as 1915 in the Appendix to her father's book entitled On the Writing of English ${ }^{1}$. The essay "Upon the Quality called "Romance"" is unattributed, but George Townsend Warner's comment on the piece is illuminating:

Here, finally, is an even younger piece of stuff, the work of a fifteen year old. Its writer would now criticise it ferociously on the ground that it is altogether too elaborate or fanciful...But it serves my purpose.

(qtd. Harman 1989, p.20) 
Her mentor in music, Percy Carter Buck, was a brilliant musician and scholar. Rupert Gough in his article in the journal Choir \&Organ summarises the breadth of his learning and accomplishment: 'Percy Buck was many things: organist, composer, editor, author, teacher, educationalist, mathematician and Hebrew scholar' (Gough 2005, p.19). In her biography of Warner, Claire Harman states that:

When she [Warner] was sixteen she began to study music with Dr. Buck: piano and organ... [and] the history and theory of music and composition. By 1911 she was composing regularly, setting favourite poems to music and writing among other things a set of piano variations.

(1989, pp.21-22)

The influence of these gifted teachers would have contributed a great deal to Warner's success in both writing and music, and it was the latter that appears to have been uppermost in Warner's life at this time for, as she wrote to the American composer Paul Nordoff, 'when I was young I composed, and was convinced that music was my metier' (Warner 1982a, p.48).

The initial choice between music and writing as a major occupation - and later as a way of having to provide for herself - may have been brought about by the death of her father. George Townsend Warner died suddenly in 1916 and with his death Warner lost her literary exemplar and mentor. Buck was still at Harrow and was part of the musical Establishment in London, with connections at The Royal College of Music. He may have supported Warner's move to London where these connections would have been useful to an aspiring young composer. It is possible that he introduced Warner to Dr. Richard Terry, Organist and Choir Master at Westminster Cathedral which brought about the advancement of her musical scholarship as one of the Editors of Tudor Church Music ${ }^{2}$. 
When Warner moved to London she joined the Bach Choir as a singing member. Several eminent composers and music teachers from the Royal College of Music, Sir Hugh Allen, Sir Hubert Parry and Ralph Vaughan Williams among them, held posts on the Bach Choir Committee, and it is probably here that she met Vaughan Williams who later conducted the Choir. It was his Sea Symphony that Warner first sang in December 1916 - her name is listed on the programme (Bach Choir Archive).

Warner's life did appear to be devoted to music during the later years of the First World War, as can be established by her letter to Herbert Howells who was working temporarily with the Tudor Church Music project: 'I expect you feel as I do - that there's enough in this job to keep one learning all one's life: it's not a bad feeling' (Herbert Howells Archive). It is probable that Warner was also writing at this time, but it was her music that she first ventured into the public domain by entering the Carnegie Music Publication Competition. This was the idea of Sir Henry Hadow, who had also been instrumental in encouraging the Carnegie (UK) Trust to initiate the Tudor Church Music project. The idea for the competition was put before the Trust as early as 1913 but took some years to come to fruition. The first competition was held in 1917 which was also the first year that Warner worked with Terry transposing Tudor notation and undertaking research at the British Museum.

The object of the competition was to "encourage British Composers in the practice of their art'. There were five categories of musical style and the awards were to be annual, with as many as six winners who, in the opinion of the Adjudicators, would have entered work that would 'constitute the most valuable contributions to the art of music' (Carnegie GD 281/41/225). The minutes of the Carnegie Music Standing Sub Committee of $24^{\text {th }}$ February 1917 enlarge on how it had been received in the musical press:

Considerable interest has been caused in the musical world by the Trustees' 
announcement of the Scheme for the Publication of Musical Compositions. A number of articles on the subject have been written in the public press, mostly of a favourable and commendatory nature.

(Carnegie GD 281/38/46)

The competition was adjudicated by three figures from the musical Establishment, two of whom, Sir Henry Hadow, Principal of Armstrong College, Newcastle upon Tyne, and Sir Hugh Allen, Choreagus of the University of Oxford, would have been well known to Warner had their anonymity not been preserved. The third member of the Board of Adjudication was Donald Tovey, Reid Professor of Music at the University of Edinburgh.

Their report highlighted three factors which had ensured the success of the first year of the scheme. One was the high level of entry to the competition and the diversity of the work submitted; the second was that the winners' work would stand comparison with the best in Europe, and the third, and perhaps most interesting, was the high level of competence of most of the entries: 'there are many, even from remote and unknown composers, which show not only considerable talent but a great command of technical equipment and resource' (Carnegie GD 281/41/225). Winnowing the competition entries was a complicated business entailing levels of successive rereading and rejection by the Adjudicators until 'the list had been brought to include those works alone which in addition to their technical equipment commended themselves by more marked individuality of theme or some special mastery of treatment' (Carnegie GD 281/41/225).

The outcome of this first competition was not the six winners that had been expected, but seven winners whose work was to be published, together with commendations for a further seven compositions which might have been winners in a less hotly contested year. Ten further works which 'might also be brought before the notice of musical societies in search of new works' were also cited 
(Carnegie GD 281/41/225). Among the winners of the competition were Frank Bridge, Herbert Howells, Sir Charles Villiers Stanford and Ralph Vaughan Williams, many of whom were well established composers by this time: Stanford had become Professor of Composition at the Royal College of Music in 1883 and subsequently taught Vaughan Williams, Frank Bridge and Herbert Howells.

This first competition may have had exceptionally talented entrants but twenty four, not the six planned, were deemed good enough to be noted and Warner was not amongst them: possibly her work fell amongst those thought to be 'decent respectable exercises which would have been more in place at an academic examination' (Carnegie GD 281/41/225). This would reflect her intellectual ability and the highly technical nature of the transcription of Tudor church music that she was undertaking at the time. Unfortunately the Adjudicators' report on Warner's work, together with other administrative paperwork including the card records 'kept in the office for reference at later stages' (Carnegie GD 281/41/225) have not survived in the Carnegie Archive, so the reasons her work was not seen to properly fulfil the remit of the competition must remain conjectural.

The composition entered by Warner was entitled Folk Tunes for Viola \& Orchestra and may have had vocal content. It would be surprising if it had not, considering her work with Tudor Church Music, and the provenance of folk tunes and tales in relating folklore and custom; themes used by Warner in her later writing. It was also topical as Cecil Sharp was leading a folklore revival in England during the first decades of the twentieth century and Warner would have been aware of other composers who were involved in this trend. Warner's own interest in folk tunes is emphasised in a letter to Ursula Vaughan Williams after the death of her husband, the composer, Ralph Vaughan Williams, for she discusses folksong and gives an instance of compelling curiosity of many years past: 
The words \& tunes of folksongs are part of the same thing. Long acquaintance has made them so; they fit into each other like the blade and the handle of a scythe swung through many summer hayfields. Dear Ralph! He'd rise like a fish to a tune. I remember long ago meeting him after a concert at the Queen's Hall, meeting on the staircase crowded with departers, \& saying that one of the folksongs which Cecil Sharp found surviving in the Appalachians also survived in $\mathrm{Mr}$ Ironsides the butcher at Wool. 'Which one?' said he, 'Sing it.' And standing in that jostle and shuffle of concertgoers, I sang it obediently.

(Warner 1982a, p.276)

In 1917 Warner would not have known Vaughan Williams well and perhaps by following that trend in music in her competition entry she did not display the originality that her later literary writing possessed in such abundance. The Carnegie Music Publication Competition was held each year for another decade but she never entered it again, even though she was said to be a pupil of Vaughan Williams. This assertion is given by the poet Arnold Rattenbury, writing on Ivor Gurnney, a fellow poet and a composition pupil of Vaughan Williams at the Royal College of Music. In his article he comments that 'Sylvia Townsend Warner, another of Vaughan Williams' composition students, had just completed her Requiem, a setting of Whitman for string quartet and voice' (Rattenbury 1999). Walt Whitman was a poet to whose work Vaughan Williams and other composers were drawn, and Vaughan Williams set his poetry to music often, so it is possible that he may have influenced Warner in selecting Whitman for her work.

There is no record of Warner having been a student at the Royal College of Music where Vaughan Williams taught at this time, so it must be assumed that if she did have lessons in composition from him it was as a private 
pupil. Interestingly, Warner kept this piece although she had previously destroyed much of her music, as her diary entry for 17 November 1928 notes, and it is now in the Warner archive. What survives is complex, incomplete and titled in Warner's own hand Memorial - Rhapsody for Solo Voice and String Quartet 1918-1920 (Warner 1920b).

It is worth noting that Warner's composition for the Carnegie prize appears to be very different from the music of Amold Schoenberg with whom it is said, and widely quoted, she was going to study composition in 1914. Schoenberg had begun his early atonal compositions - music that does not follow any system of key or mode - around 1909 which, according to Alison Latham, 'sound like products of the subconscious' (2002, p.1116). Warner would have had to have supplied Schoenberg with a collection of her own work for him to assess in order for him to be convinced that there could be mutual understanding and benefit from Warner becoming his pupil.

Claire Harman's source for this information published in her biography of Warner (Harman 1989, p.26) was William Maxwell, Warner's friend and editor at the New Yorker magazine. It is possible that Maxwell misremembered the conversation with Warner, since what little music of Warner's that is known is not atonal and it is doubtful that it would have been of interest to Schoenberg. Helen MacLeod also refers to Warner's plan to study with Schoenberg (MacLeod 1989, p.21), citing 'autobiographical notes' as her source, but as no specific reference is given, these notes remain unlocated and the information cannot be verified. Furthermore, the Schoenberg archive ${ }^{3}$ has no record of correspondence with either Warner or Buck, suggesting, perhaps, that this 'plan' was never acted upon.

Warner's musical life does appear complex: composing was evidently a private matter, very different from the public nature of her work in musicology, and this despite moving in the same sphere as well known musicians from the Royal College of Music and the Bach 
Choir. No mention of her work as a composer is made in correspondence to or from anyone in the upper levels of English music, not even her friend Herbert Howells whose talent for self-promotion, as well as composing, had seen hin rise very rapidly in the musical circles of London. Letters between Buck and Warner have not survived, but there is no retrospective mention in later Diaries of her experiments in composition with which he may have assisted her.

There is no entry either for Warner in musical publications such as A Dictionary of Modern Music and Musicians whose preface states that 'the object of this new Dictionary is to supply the musician and the general musical reader with a concise and practical survey of all modern musical activities'. (Allen, Bantock, Dent, p.v). This would corroborate the supposition that Warner had no status in the musical world of the time other than as one of the Editors of Tudor Church Music.

It is interesting, too, that Warner does not appear to have been in contact with other female musicians during these years, despite Marion Scott having set up the Society of Women Musicians whose guiding principles were 'to promote a sense of cooperation among women in different fields of music, provide performance opportunities and advice and would even help women with "regard to the business side of their professional work" (Blevins). The Society was founded in 1911, so was well established in London by the time Wamer arrived there. Sixteen years Warner's senior, Scott was an accomplished and professional violinist who had played in orchestras directed by Stanford, Parry and Gustav Holst. She had also formed the Marion Scott Quartet in 1908 with whom she was committed to performing contemporary British music, which the Quartet did in prestigious London venues such as the Aeolian Hall. Like Warner, Scott regularly attended concerts in London and it is difficult to believe that the two women were unknown to each other, particularly as Buck was known to both of them: he succeeded Scott as editor of the Royal College of Music's Magazine. Scott was also known to 
other friends of Warner's, notably Herbert Howells, himself a friend of Ivor Gurney who was a close friend of Scott's: a somewhat incestuous circle but not one that Warner broke into in order to promote her own music.

The Society of Women Musicians organised at least one conference on composing which would have been an ideal starting point for Warner's compositions to be discussed, had she wished it, and possibly performed too as the Society organised concerts as well as debates and meetings. Scott's promotional skills - she had many articles published in London newspapers and music journals when she launched the Society - would have ensured a wide and supportive audience. However, it would seem that Warner was diffident about her ability to compose and it could have been her failure to be placed in the Carnegie competition, when so many other entrants had had 'honourable mention,' that caused her to think again about music being her metier.

Another factor which the realist in Warner would have experienced in her time in London was the difficulty of being a female composer in the male-dominated sphere of music for performance. Her diary entry for the $5^{\text {th }}$ September 1958 gives a clue to this difficulty: "An invitation to give the Peter le Neve Foster Lecture on Women as Writers [to the Royal Society of Arts]...the question of why women aren't composers germane' (Warner 1994, p.250) and in the lecture that she delivered she argued that

[it] is not so much about how women wrote as about how astonishing it is that they should have managed to write at all...supposing I had been a man, a gentleman novelist, would I have been asked to lecture on 'Men as Writers? I thought it improbable.

(Warner 1982b, p.265)

Very evidently this state of affairs would have applied to musical composition too. She had breached the gender barrier in musicology and was working at the highest 
academic level in a sphere traditionally that of men and was respected for her ability. This is evidenced in a letter from Terry to the Secretary of the Carnegie (UK) Trust, dated $15^{\text {th }}$ June, 1917:

It is very necessary that someone should now go to the Bodleian and Christ Church again to collate some of my scores the vocal parts of which I don't have...if you approve, I will send Miss Townsend Warner...who is now so far advanced in her study of the old notation that she is able to tackle any kind of manuscript. The work that is to be done at Oxford she will do as weil as I should myself.

(Carnegie GD 281/41/225)

That Wamer is still attempting to compose is seen in 1919 when her literary and musical life come together in a letter to Thomas Hardy, requesting permission to set some of his poems (Warner, 1919). She was evidently still striving to produce music that would satisfy her and about which she had no reservation. The music written for 'She at his funeral' is in the Warner archive $e^{4}$.

Warner gives the reason why she had ceased to compose in answer to the question posed by Vaughan Williams just before his death in 1958: 'I had come to the conclusion that I didn't do it authentically enough, whereas when I turned to writing I never had a doubt as to what I meant to say' (1982a, p.168). It would seem, then, that in her own view she could write imaginatively about music: its emotional effect, it's technical difficulties and how it sounded - the Diaries contain many such examples - but could not produce the imaginative flowing ease when composing music that came so readily to her when writing.

When exactly writing began to gain ascendancy over music in Warner's life is unknown, but probably sometime before the short poem, The Happy Day, by 'Elsie' Townsend Warner was published in 1920 in an early volume of the journal Music and Letters (Warner 
$1920 a$, p.284), the name possibly a corruption engendered by her signature in the manuscript. This would be the first poem of Warner's to be published. It is particularly significant that it is a poem and not prose, and that it appeared in a musical journal where it was sure to be read by her peers in the music world. Unlike her music, Warner is content to share this writing of a very different nature to that which was usual for her: long articles on technical aspects of music notation for Music and Letters and other journals during the years that she worked as an editor for Tudor Church Music.

The move to a literary life does not appear to have been radical. There is little evidence that she was writing either poetry or prose with a view to earning a living by it, as she was then occupied with her editorial work in musicology. Yet her ability as a writer, even a writer of reports on libraries surveyed for Tudor Church Music, is noted by Terry who commends her wit. Her humour, and the use of musical terminology to supply it in an unorthodox way, is also evident in unpublished extracts from her later Diaries: this entry for $5^{\text {th }}$ April, 1930 for example, when Warner had ceased to sing as a member of the Choir

\begin{abstract}
at five began a Bach Choir performance of the Matthew Passion...Dorothy Silk...was damnably mannered and coquettish...in fact she wanted thrashing throughout. As for the vibrato it grows worse and worse; very soon she will be indistinguishable from an electric drill, and they will be able to use her $\mathrm{E}$ flat to take up Piccadilly.
\end{abstract}

(Unpublished diary, 1930)

The change of emphasis in Warner's life from music to writing probably came about during the early years of the 1920s. The detailed research work for the Tudor Church Music volumes was complete. The first volume had been published in 1922 and others quickly followed. Warner's work now was detailed and time-consuming, and perhaps 
the excitement of being part of a new movement in musicology had passed. The Diaries describe tedious editorial meetings and much revision work; some of it necessarily against the grain as the editors operated democratically and the majority vote over a problem in a manuscript carried, despite the transcribers' belief in their own interpretations.

But for all that writing may then have been occupying more of Warner's interest and creativity; it was also a time when the strands of her artistic identity appear closely woven. She was evidently working hard at both disciplines as work on Tudor Chtrrch Music continued until 1929 when the final volume appeared. By this time she had had three novels - Lolly Willowes, Mr Fortune's Maggot and The True Heart - published, as well as two collections of poetry: The Espalier and Time Importuned. Warner was as diffident about promoting her literary work as she had been earlier about her music. It was her friend Stephen Tomlin who showed her poems to David Garnett, bookshop owner and writer, who in turn showed them to Charles Prentice of the publishing house Chatto and Windus, who lost no time in publishing them and requesting more.

The Carnegie (UK) Trust had by then very firmly rejected the possibility of financing a further ten volumes of Tudor Church Music, although the editors had already established enough material for them. On the strength of her participation in that project, Warner could have continued working in musicology. There is evidence of this in a letter from Dom Anselm Hughes, himself a musicologist, whose opinions on the editorial work of the volumes Warner had taken issue with in Music and Letters in the early years of the project. Warner's Diary entry reads:

A letter from Anselm suggesting to me once more a seat on the P.M.M.S Council ${ }^{5}$. The old gentleman who had previously vetoed me as a female has asked Anselm if he 
might unreservedly recant. (Unpublished diary, 1930)

Warner's reaction to Carnegie's denial of further funding, and her refusal of Hughes and his prejudiced fellow Council member, is encapsulated in a letter to David Garnett, reminding him how his efforts on her behalf had changed her life:

If you hadn't intervened, dear David, I should have gone on writing poems \& hiding them in hatboxes, \& being an ornament to the Plainsong \& Medieval Society, and publishing such learned treatises on the Hoquet in the $14^{\text {th }}$ cent. at long intervals. How glad I am you intervened. And how grateful.

(Warner 1982a, p.291)

This letter was written in 1976 after a lifetime of writing. In 1928 the place of music in Warner's life is viewed by her in a different way. Dining with Charles Prentice, her publisher and friend, she writes in her Diary: 'He began to ask about my music and I felt curiously as though I had this secret past which I was rather proud of being so inalienably mine by renunciation' (Unpublished diary 1928). In this ambiguous statement music appears both integral to Warner's identity and something that she has cut herself off from, almost sacrificially. But the helix of music and literature is not quite severed; it is in fact rearranged: music is now in Warner's writing, and to great effect as, Gillian Beer describes:

Her training as a transcriber of music and her gifts as a musician move into the pacing and timbre of her writing: she has a particularly acute ear for the nuanced hesitations of dialogue: the narrative presence of her work relies often on the unvoiced rests between sentences for its 
effect, and she also draws freely on musical experience in describing emotional states.

(2004, p.24)

Warner had come full circle: from early work in musicology, via seemingly unsatisfactory attempts at composition, to writing in which music is integral to the structure. Her metier had, indeed, been transformed.

\section{NOTES}

1. For a fuller discussion of this see Harman, 'Sylvia Townsend Warner and Romance' pp. $39-50$, below.

2. This aspect of Warner's musical life is discussed in detail in Searle, "Sylvia Townsend Warner and Tudor" Church Music' pp. 69 - 88, below.

3. The Schoenberg archive has an index to all dated letters sent and received, organised by sender, and another to all undated letters, again organised by sender. Both indices were checked for references to Warner and Buck for the years 1906 to 1916, but none was found.

4. 'She at his Funeral' was also performed in the 'Words \& Music of Sylvia Townsend Warner' concert at St Anne's College, Oxford on $3^{\text {rd }}$ May 2008. Mezzosoprano: Nicola Beckley; Piano: Simon Whalley; Members of Keble College Choir. (Recorded by JoeBellSound.com).

5. A revised version of this poem was published in The Espalier (1925); collected in Warner (2008), New Collected Poems ed. C. Harman. Manchester: Carcanet, p.42.

6. The Plainsong and Medieval Music Society.

WORKS CITED

ALLEN, H, BANTOCK, G.; DENT, E. eds. (1924). A

Dictionary of Modern Music and Musicians. London and Toronto: J.M. Dent.

BACH CHOIR ARCHIVE, Bach Choir Programme note, 12 December 1916. Special Collections, Royal College of Music, London. 
BEER, G. (2004) 'Sylvia Townsend Warner: The Centrifugal Kick'. Journal of the Sylvia Townsend Warner Society, pp.18-31. Rpt. from JOANNOU, M. ed. (1998) Women Writers in the 1930s. Gender, Politics and History. Edinburgh: Edinburgh University Press. pp. 7686.

BLEVINS, P. (n.d.) 'Marion Scott[:] Critic, Champion of Contemporary Music and Women'. <www.musicwebinternational.com/Scott/biog.htm $>$ Accessed 13/12/11. CARNEGIE UNITED KINGDOM TRUST Tudor Church Music archives files GD 281/41/224 - 46; archive files of the Standing Music Sub-Committee which oversaw the project at GD 281/38/46-58. National Archives of Scotland, Edinburgh.

GOUGH, R. (2005) 'Full of Surprises', Choir \& Organ. May/June, pp.18-20.

HARMAN, C. (1989) Sylvia Townsend Warner. A Biography. London: Chatto \& Windus.

HOWELLS, H. Archive. Royal College of Music, London.

LATHAM, A. ed. (2002) Oxford Companion to Music. Oxford: Oxford University Press.

MACLEOD, Helen (1989) 'The Novels and Short Stories of Sylvia Townsend Warner'. Book and Magazine Collector No.65, August 1989, pp.20-27.

RATTENBURY, A. (1999) 'How the sanity of poets can be edited away'. London Review of Books. Vol.21, No.20 14 October, pp.15-19. (Consulted online $<\mathrm{http} / /$ www.Irb.co.uk/v21/n20/arnold-rattenbury/howthe-sanity-of-poets-can-be-edited-away>)

SCHOENBERG Archive $<$ http://www.usc.edu/libraries/archives/schoenberg/letters. $\underline{\mathrm{htm}}>$ Accessed 14/12/11/

TOMLIN S. and WARNER, S.T. (1921) 'The Lonely Traveller'. 4 pages of MSS. Music and words in Warner's writing.

WARNER, S.T. (1919). Letter dated 5 December to Thomas Hardy, Writers' Gallery. Dorset County Museum, Dorchester. 
(1920a) 'A Happy Day'. Music and Letters. Vol. 1 , pt. iv, p.284.

(1920b) 'Memorial - Rhapsody for Solo Voice and String Quartet 1918-1920'. 30 pages of Mss music in Warner's writing. Warner Archive, Dorset County Museum, Dorchester.

(1925) The Espalier. London: Chatto \& Windus. (1926) Lolly Willowes. London: Chatto \& Windus. (1927) Mr Fortune's Maggot. London: Chatto \& Windus.

(1928) Time Importuned. London: Chatto \& Windus.

(1929) The True Heart. London: Chatto \& Windus.

(1982a) Letters ed. W. Maxwell. London: Chatto \& Windus.

(1982b) 'Women as Writers' in Collected Poems ed. C. Harman. Manchester: Carcanet, pp.265274.

(1994) Diaries. ed. C. Harman. London: Chatto \& Windus.

(2008) New Collected Poems. ed. C. Harman. Manchester: Carcanet.

Unpublished diaries 1928; 1930. Warner Archive, Dorset County Museum, Dorchester. undated music. 'She at His Funeral'; words by Thomas Hardy (Wessex Poems and other Verses, 1898). Warner Archive, Dorset County Museum, Dorchester. 